\title{
Fabric Enrichment Techniques: A Source of Income Generation for Rural Women
}

\author{
Sunita Ahuja ${ }^{1 *}$ and Balwan Singh Mandal $^{2}$ \\ Krishi Vigyan Kendra, Ambala-134003, India \\ *Corresponding author:
}

\begin{tabular}{|c|}
\hline Keywords \\
\hline $\begin{array}{l}\text { Rural women, } \\
\text { Enrichment, } \\
\text { Training, } \\
\text { Entrepreneur }\end{array}$ \\
\hline Article Info \\
\hline $\begin{array}{l}\text { Accepted: } \\
\text { 20 January } 2019 \\
\text { Available Online: } \\
\text { 10 February } 2019\end{array}$ \\
\hline
\end{tabular}

A B S T R A C T

\section{Introduction}

Poor educational status of Indian women becomes a challenge in the path of their development and growth. Empowering women to become economically self-reliant in the field of their interest can be a boon to develop confidence. Krishi Vigyan Kendra plays a great role by organizing the needEntrepreneurship-development and income-generating activities are feasible solution for fabric painting; embroidery; tie and dye techniques; cushion and bag-making etc. One sewing machine (Usha Allure) along with accessories was given to all these women so that they can start their small entrepreneur for their economic upliftment. Regular monitoring was done to cover-up their felt problems in using the latest techniques. The adoption level was assessed on the basis of expressed opinion by the beneficiaries. Improvement in quality life was measured with the help of various parameters in the light of various activities like demonstrations, trainings, exhibitions, group discussions etc. The maximum impact was found in increase in knowledge and skill up gradation followed by increase in confidence and domestic savings. The economic analysis of the successful women among the trainees was also worked out and the most liked activities were found to be cushion making followed by tie and dye, bag-making. The maximum utilization of this machine was found for pikoo, inter-locking and pouncha-designing. 
al., (2012) highlighted that stitching is a strong tool of viable income generation activity for rural women. Now-a-days, people are more conscious about looks. Women in the rural areas are involved in different clothing related activities. Scientific techniques and complete technology, in form of theory and practical, required to benefit farm women to increase their family income in terms of money as well as savings.

\section{Materials and Methods}

The present study was conducted in Ambala district of Haryana state (India). Krishi Vigyan Kendra, Ambala, an extension unit of Chaudhary Charan Singh Haryana Agricultural University, Hisar, organized the training programmes for the women of scheduled cast on cutting, designing and stitching. One sewing machine, with latest technique, was provided to them so that they can add income to their profession.

To study the benefit from these techniques, the three year data, i.e. from 2013-14, 201415 and 2015-16, on fabric enrichment was pooled. The women, between the age of 18-45 years and having an experience in garment construction, were selected for training purpose. The total numbers of respondents were 180. Adoption and impact was assessed on the basis of expressed opinion of the beneficiaries and success stories of the women. The schedule of question was prepared and asked by the beneficiaries via multiple choice question having three options i.e. strongly agree, agree and disagree with a score of two, one and zero. The scores so obtained were totaled and average was calculated.

\section{Results and Discussion}

The data of three year training programs was pooled to study the economic impact and the adoption level assessed according to their feedback. Kaur et al., (2011) revealed that the highest mean score were found for stain removing and dyeing methods which indicated that the rural women required more training in the sub-areas of clothing. Various fabric enrichment techniques i.e. drafting techniques; designed fabric; neck and collar designing; embroidery; fabric painting; tie and dye techniques; bag and cushion making etc. were demonstrated during the training. Saroj Bala et al., (2006) highlighted that 63.3 per cent trainees had low opinion regarding drafting techniques. The training on basic concept of drafting techniques, designed fabric, neck and collar designing were most liked by the trainees.

The adoption of various techniques was clearly visible by improved quality of their stitched garments (Fig. 1). The young girls of rural areas, who are educated, had interest to wear latest designed clothes. Sometimes, they are not able to afford ready-made garments from market. The Krishi Vigyan Kendra imparted practical training on designer clothes such as plazzo, long skirt, trousers, sari tucking, balloon salwar, lehngas, jackets, long suit, etc. Home stitching is preferred over ready-made garments, as it saves 30-70 per cent of their family income (Sunita et al., 2011). Hand embroidery takes time and is costly too, so machine embroidery, especially on neck and poncho, was adopted by 55 per cent women. Fabric painting with the help of stencils and block was adopted by 20 per cent as painting by brush is not possible by all age group. Women are getting handsome profit by poncho designing. The machine maximum utilized for interlock, pikoo work. Very fast learning was observed in tie and dye techniques during trainings. The women liked the bag, cushion and soft toys making, mostly and resulting to start taking order of these. The adoption was clearly viewed as expressed by their customers. They practiced and added 
all these techniques with their stitching profession to increase their income and meet the market demand. The large percentage of respondent had favorable attitude towards trainings organized by KVK (Sulakshna
Dogra, 2008). The data in table 1 revealed that after intervention and imparting skill 88 percent women have adopted fabric enrichment techniques at household level.

Table.1 Impact assessment of fabric enrichment techniques

\begin{tabular}{|c|l|c|c|c|}
\hline Sr. & \multicolumn{1}{|c|}{ Opinion } & \multicolumn{3}{|c|}{ Impact analysis (percentage) } \\
\cline { 2 - 4 } no. & & Strongly agree & Agree & Disagree \\
\hline 1. & Increase in knowledge & 52 & 48 & 0 \\
\hline 2. & Up gradation of skill & 32 & 62 & 6 \\
\hline 3. & Adoption at household level & 41 & 47 & 12 \\
\hline $\mathbf{4 .}$ & Increase in confidence & 28 & 52 & 20 \\
\hline 5. & Know latest technique and designing & 35 & 65 & 0 \\
\hline 6. & $\begin{array}{l}\text { Saving money in terms of reducing } \\
\text { expenditure }\end{array}$ & 37 & 63 & 0 \\
\hline 7. & Benefits of latest model of sewing machine & 72 & 28 & 0 \\
\hline
\end{tabular}

Table.2 Monthly income (approximately) reported by trainees

\begin{tabular}{|c|c|}
\hline Monthly income category (INR) & Percentage of trainees (per cent) \\
\hline Up to 3000 & 56.11 \\
\hline $\mathbf{3 0 0 0}$ to 6000 & 35.55 \\
\hline $\mathbf{6 0 0 0}$ to 9000 & 04.45 \\
\hline Above 9000 & 03.89 \\
\hline
\end{tabular}

Fig.1 Percent adoption of various fabric enrichment techniques at household level

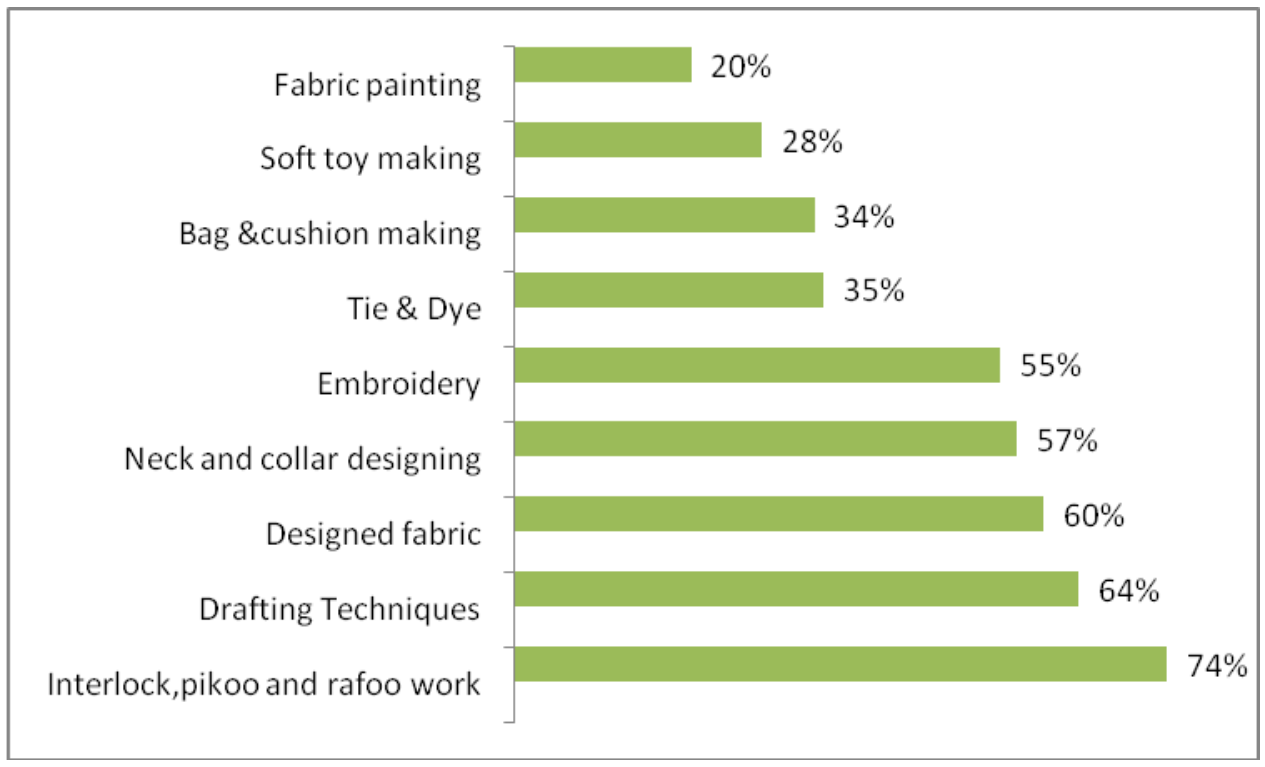


All women were benefited by latest model of sewing machine as it speeds up the work in terms of easy and comfort to use; designed fabric ready easily and pikkoo interlock work be done by their own level for which they have to go city earlier and thus, saves money in terms of reducing expenditure. Economic analysis revealed that the family income and status upgraded.

The table 2 highlighted that majority of women earned up to INR 3000 per month as reported by them. Krishna Srinathan (1992) in her study also highlighted that additional income in the hands of women have large positive impact than if it is with men, because women are more likely to spend the additional income for the betterment of their family.

It is evident from the findings that Krishi Vigyan Kendr is able to bring the significant change in socio-economic status as-well-as the knowledge of trainees. Significant increase in knowledge was recorded for all components of fabric enrichment techniques and up-gradation of skill.

Continuous planned efforts and follow up action required and also special lectures for loaning and marketing facilities required.

\section{References}

Ahuja, S., Bhatia, J. N., Thakral, S. K. and Siwach, M. 2010. Empowering rural women through home science extension activities - An impact analysis, presented in national seminar on achieving excellence in home science-changing needs and future directions in $21^{\text {st }}$ century held at Panipat on 24-25 September, 2010: 81.

Dogra, S., Siwach, M., Dhaiya, M. and Goyal, S. P. 2009. Empowerment of rural women through training program. Paper presented in national seminar of empowerment of women: Emerging challenges held at PAU, Ludhiana on 18-19 Feb., 2010: 79.

Khambra, K., Rose, N. M. and Singh, S. Jeet. 2010. Adoption feasibility of clothing related technologies, Abstract published in national seminar of the society for Agricultural and Rural institutions on Empowerment of women: Emerging challenges held on 18-19, Feb., 2010 at PAU, Ludhiana: 14.

Krishna Srinath. 1992. Empowering rural women through extension educationAn action research in a fishing village. Avinashilingam institute of home science and higher education for women, Coimbatore

Sabharwal, K. and Kaushik, R. D. 2012. Stitching: A staunch tool to rural women empowerment. Abstract published and presented in national seminar on scenario of women in agriculture and future projections held at CCS HAU, Hisar on 16-17 Feb., 2012: 79-80.

Saroj Bala. 2006. Standardization of paper pattern of kurta-pyjama for preadolescent boys, pp. 98.

\section{How to cite this article:}

Sunita Ahuja and Balwan Singh Mandal. 2019. Fabric Enrichment Techniques: A Source of Income Generation for Rural Women. Int.J.Curr.Microbiol.App.Sci. 8(02): 2795-2798. doi: https://doi.org/10.20546/ijcmas.2019.802.328 